FACTA UNIVERSITATIS

Series: Philosophy, Sociology, Psychology and History Vol. 20, No 1, 2021, pp. 39 - 53

https://doi.org/10.22190/FUPSPH2101039R

Original Scientific Paper

\title{
PERFECTIONISM IN THE CONTEXT OF THE REVISED REINFORCEMENT SENSITIVITY THEORY
}

\author{
UDC 159.923
}

\author{
Kristina Ranđelović, Snežana Stojiljković
}

University of Niš, Faculty of Philosophy, Department of Psychology, Serbia

\begin{abstract}
The main goal of this research was to examine the role of personality traits in predicting the two aspects of perfectionism - maladaptive evaluation concerns and positive strivings. Personality traits were postulated by the Revised Reinforcement Sensitivity Theory, while the dimensions of perfectionism were defined by the Model of Perfectionism developed by Frost et al. The sample consisted of 299 students of the Faculty of Philosophy in Niš (79.3\% were female), aged 19 to 29 years $(M=20.34 ; S D=$ 1.83). The instruments used were: the Reinforcement Sensitivity Questionnaire (RSQ), and the Multidimensional Perfectionism Scale (MPS). The main takeaways of this research indicate that the Behavioural Inhibition System (BIS) is the strongest and positive correlate of maladaptive evaluation concerns, followed by Freeze and Fight. Unlike personality defence systems, the Behavioural Approach System (BAS) shows a negative correlation with the abovementioned criterion. The total percentage of explained variance for maladaptive evaluation concerns is $23 \%$. When positive strivings are used as the criterion, BAS is seen as a positive correlate only in the first step of the hierarchical regression analysis. However, Flight and Fight represent consistent and positive correlates of this criterion. The total percentage of explained variance for positive strivings is 6.9\%. The findings are consistent with the Revised Reinforcement Sensitivity Theory and available empirical findings from previous studies. Moreover, the results indicate that in the context of the abovementioned personality theory, maladaptive evaluation concerns and positive strivings can be understood as maladaptive forms of perfectionism, which deviates from previous understandings of perfectionism.
\end{abstract}

Key words: perfectionism, maladaptive evaluation concerns and positive strivings, the Revised Reinforcement Sensitivity Theory.

Received July 15, 2020 / Accepted November 30, 2020

Corresponding author: Kristina Ranđelović

University of Niš, Faculty of Philosophy, Ćirila i Metodija 2, 18000 Niš, Serbia

E-mail: kristina.randjelovic@ filfak.ni.ac.rs

(ㅇ 2021 by University of Niš, Serbia | Creative Commons License: CC BY-NC-ND 


\section{INTRODUCTION}

Although there are numerous definitions of perfectionism, this personality trait is mostly defined in the context of accomplishment. Therefore, perfectionism represents a tendency towards high standards of accomplishment and perfection in various areas of life (Stojiljković 1998; Stojiljković, Todorović, Dosković, \& Todorović 2011). This is a multidimensional construct, and perfectionism can be seen through different dimensions, intrapersonal and interpersonal context, but also as a negative and positive personality trait.

Perfectionism can manifest itself in the form of an adaptive aspiration for personal growth and development or accomplishment but also in the form of non-adaptive, neurotic and defensive traits (Hamachek 1978; Flett, Hewitt, Blankstein, \& Mosher 1991; Flett, Blankstein, Hewitt, \& Koledin 1992; Milojević, Stojiljković, Todorović, \& Kašić 2009; Shafran \& Mansell 2001, Stojiljković 1998; Stoeber \& Otto 2006). Many studies around the world and in our country have confirmed the dual structure of this phenomenon by indicating its adaptive and maladaptive aspects (Frost, Marten, Lahart, \& Rosenblate 1990; Frost, Heimberg, Holt, Mattia, \& Neubauer 1993; Slade \& Owens 1998; Slaney, Rice, Mobley, Trippi, \& Ashby 2001; Todorović, Zlatanović, Stojiljković, \& Todorović 2009).

In order to better understand the adaptive and maladaptive aspects of perfectionism, Slade and Owens (Slade \& Owens 1998) postulated a Dual Process Model of Perfectionism based on the reinforcement theory. These authors make a distinction between positive and negative perfectionism, whose common feature is setting high standards, and the key difference relates to cognitive processes, emotional states and goals that are linked to positive and negative reinforcement. Positive perfectionism is focused on gaining success, while negative perfectionism is oriented towards avoiding failure, because it is based on the fear of failure. Therefore, from the aspect of positive perfectionism, cognition and behaviour are aimed at achieving high standards, which is usually accompanied by positive reinforcement, i.e., the person achieves success, which in turn results in the increase of selfesteem and positive emotional states (e.g., pleasure, happiness, pride, euphoria) (Saboonchi \& Lundhb 2003). On the other hand, negative perfectionism is characterized by cognition and behaviour that is aimed at setting unrealistically high goals and behaviour standards, in order to ultimately avoid negative consequences (e.g., criticism, rejection, etc.).

In addition to the indisputable adaptive and maladaptive nature of perfectionism, there are concepts that observe this construct through the intrapersonal and interpersonal dimension. Thus, for example, Hewitt and Flett (1991) identify three types of perfectionism: 1) self-oriented perfectionism; 2) socially prescribed perfectionism, and 3) other-oriented perfectionism. Self-oriented perfectionism has both a positive and a negative association with psychological well-being (Hewitt \& Flett 2004), as well as a positive association with conscientiousness (Klibert, Langhinrichsen-Rohling, \& Saito 2005) and rumination (Randles, Flett, Nash, McGregor, \& Hewitt 2010), but also a negative association with selfactualization, unconditional self-acceptance, and tolerance for failure (Flett, Besser, Davis, \& Hewitt 2003). Other-oriented perfectionism does not correlate with psychological well-being (Hewitt \& Flett 2004). Socially prescribed perfectionism is a maladaptive form of perfectionism because it is a positive correlate of depression, suicidal thoughts, anxiety, stress, motivation to avoid failure and rumination (Blankstein, Lumley, \& Crawford 2007; Randles et al. 2010). 
Frost et al. (Frost, Marten, Lahart, \& Rosenblate 1990) define perfectionism as the pursuit of high standards, appreciating order and organization, and the tendency to avoid mistakes, which entails indecision in taking action. According to these authors, perfectionism involves attaching great importance to past and present parental evaluations. In this way, perfectionism is defined as a construct that encompasses six dimensions, which can be further classified into two higher-order factors. The first factor is called "maladaptive evaluation concerns" and it includes four lower-order factors (concern over mistakes, parental expectation, parental criticism, and doubts about actions). This factor reflects the negative type of perfectionism because, above all, it correlates with negative affectivity. The second factor is called "positive strivings" and it includes two aspects - personal standards and organization, which indicates the setting of high standards, as well as the preferences for order and organization. Therefore, this factor indicates positive perfectionism (Frost, Heimberg, Holt, Mattia, \& Neubauer 1993). This Multidimensional Model of Perfectionism can also be interpreted in relation to the intrapersonal and interpersonal dimension. Personal Standards, Doubts about Actions, Concern over Mistakes, and Organization belong to the intrapersonal dimension of perfectionism, while Parental Expectations and Parental Criticism refer to the interpersonal aspect of this construct (Lo \& Abbott 2013). When comparing the concepts and operationalizations of perfectionism proposed by Hewitt \& Flett (1991a) and Frost et al. (Frost et al., 1990), the results show that there are two common and basic dimensions (Frost, Heimberg, Holt, Mattia, \& Neubauer 1993). The first dimension, which can also be called perfectionist strivings, includes personal standards, organization, self-oriented perfectionism, and other-oriented perfectionism. The second dimension, or perfectionistic concerns, refers to concern over mistakes, doubts about actions, socially prescribed perfectionism, parental expectations, and parental criticism. Moreover, the results of a study conducted by Frost et al. (Frost et al. 1993) show that only maladaptive evaluation concerns are positively associated with negative affectivity and depression (and are not associated with positive affectivity). In contrast, positive strivings are positively correlated with positive affectivity (and are not associated with negative affectivity and depression). Numerous studies, whose detailed and thorough overview is provided by Stoeber and Otto (2006), support the fact that perfectionist aspirations are positively correlated with various positive characteristics (e.g., positive affectivity, life satisfaction, active coping styles, accomplishments), and are not associated or are negatively associated with negative characteristics (e.g., negative affectivity, maladaptive coping styles, and interpersonal problems). On the other hand, perfectionistic concerns are positively correlated with various negative characteristics.

In order to thoroughly explain and understand perfectionism, it is very important to examine the dimensions of perfectionism in the context of personality theories and models, based on the psycholexical and psychobiological paradigm (Stoeber, Corr, Smith, \& Saklofske 2018). The Revised Reinforcement Sensitivity Theory (rRST; Gray \& McNaughton 2000), which represents the psychobiological personality theory, was chosen as the reference framework of this research. The rRST provides an opportunity to explain individual differences in personality and psychopathology. Individual differences in sensitivity to positive and negative reinforcement may be a determinant of adaptive or maladaptive aspects of perfectionism (Slade \& Owens 1998). Therefore, the rRST represents a suitable theoretical framework for research because it postulates the existence of three emotionalmotivational systems that are at the core of cognitive and motivational processes, as well as emotions associated with negative and positive reinforcement. Those are the following 
systems: 1) Behavioural Approach System (BAS); 2) Behavioural Inhibition System (BIS) and 3) The Fight-Flight-Freeze System (FFFS).

BAS activates in response to reward signals and all appetitive stimuli, and is the basis of approach behaviour that aims to obtain a reward, but also to avoid punishment. At the level of personality traits, BAS above all corresponds to impulsivity (Gray 1987), but also to positive emotionality and extraversion (Corr \& Cooper 2016; Depue \& Collins 1999; Smillie, Pickering, \& Jackson 2006). Emotions associated with the activation of this personality system are "anticipatory pleasure" or hope, that is, something resembling an "excitement attack" or high pleasure (joy) (Corr \& Cooper 2016). New and exciting situations provoke reactions from the domain of the approach behaviour system. BIS is a defensive approach system, which aims to assess the threat, control behaviour and resolve various types of conflicts. Therefore, the subjective assessment of the threatening componential situation is related to the BIS and can, but does not have to, be based on reality (Smederevac, Mitrović, Čolović, \& Nikolašević 2014). At the level of personality traits, BIS corresponds to anxiety. FFFS is a defensive avoidance system and is activated by a wide range of aversive stimuli. It includes three subsystems, each with its own specific emotional and behavioural reactions. These are Fight (anger), Flight (fear), and Freeze (panic). The main role of FFFS is to protect oneself from danger, and behavioural responses related to this personality domain largely depend on the social context (Krupić \& Dinić 2017; Ranđelović 2016; Ranđelović, Smederevac, Čolović, \& Corr 2018) and subjective threat assessment. Thus, while BAS is associated with approach behaviour, positive reinforcement, and positive affectivity - BIS and FFFS represent defensive personality systems (different defensive actions - approach/avoid), associated with negative reinforcement and negative affectivity.

The following findings emerged after the review of available studies on the relationship between oRST/rRST and perfectionism. In a study conducted by Flett et al. (Flett, Hewitt, Oliver, \& Macdonald 2002), all three types of Hewitt's and Flett's tripartite model of perfectionism (1991) show positive correlation with BIS. Self-oriented perfectionism has a positive correlation with BAS (reward responsiveness and drive). These findings were replicated in a larger sample by O'Connor and Forgan (2007). In contrast, Kaye, Conroy, and Fifer (2008) claim that there is a positive correlation between BIS and self-oriented perfectionism and socially prescribed perfectionism, but not with other-oriented perfectionism. Moreover, BAS (reward responsiveness, drive, and fun seeking) is positively associated with self-oriented perfectionism, but is negatively associated with socially prescribed perfectionism. In two samples from the student population, Randles et al. (Randles, Flett, Nash, McGregor, \& Hewitt 2010) noticed a positive correlation between BAS reward responsiveness, BAS drive, and BIS, while socially prescribed perfectionism showed only positive association with BIS. Unlike these findings, results relating to other-oriented perfectionism and personality systems are mixed. In one sample, other-oriented perfectionism had a positive correlation with BIS, BAS reward responsiveness, and BAS drive, while it had a negative correlation with FFFS. In the second sample, there was no significant correlation between other-oriented perfectionism and personality systems within rRST. Moreover, an unexpected finding of a positive association between socially prescribed perfectionism and BAS reward responsiveness was observed. Results of a research conducted by Stoeber and Corr (Stoeber \& Corr $2015,2017)$ suggest that self-oriented perfectionism shows a unique positive association with BAS goal-drive persistence, BAS reward reactivity, and BIS. Other-oriented perfectionism has a unique positive association with defensive fight, and a unique 
negative association with BIS. Socially prescribed perfectionism showed a unique positive association with BAS impulsivity and BIS, and a unique negative association with BAS goal-drive persistence. Taking these results into account, Stoeber and Corr (2015) conclude that self-oriented perfectionists are driven by goals and persistent in the pursuit of goals. At the same time, these perfectionists are highly reactive to both positive and negative reinforcing stimuli. Socially prescribed perfectionists are highly reactive only to negative reinforcing stimuli, and their approach-related behaviours are impulsive. Other-oriented perfectionists appear to show a reduced reactivity to negative reinforcing stimuli. Hence, both self-oriented and socially prescribed perfectionism were associated with higher BIS levels, while other-oriented perfectionists reported lower BIS levels. This means that both self-oriented perfectionists and socially prescribed perfectionism are prone to experience anxiety, while other-oriented perfectionists are not prone to experience anxiety. Moreover, other-oriented perfectionists show highly defensive fight and low anxiety (underactive BIS). These combinations of results indicate that other-oriented perfectionism shows links with aggression and psychopathy (Stoeber 2014, 2015).

While most studies on the relationship between oRST/rRST and perfectionism are based on the tripartite model of perfectionism by Hewitt and Flatt (1991), there is one study that refers to MPS by Frost et al. (1990). Chang et al. (Chang et al. 2007) claim that personal standards, which are similar to self-oriented perfectionism, show a similar structure of results as in previous studies, while only Doubts about actions is positively associated with BIS. Moreover, a review of the available literature showed that there are no studies on this particular topic in our region. Therefore, this research has potential theoretical significance because it can serve to verify the assumptions arising from rRST, but also to verify previously obtained empirical findings. Given that the study of MPS and rRST is much less common, the purpose of this study is to examine the relationship between personality systems postulated by rRST and higher-order factors within MPS (maladaptive evaluative concerns and positive pursuit of success), as well as individual dimensions within these factors (concern over mistakes, parental expectation, parental criticism, and doubts about actions, personal standards, and organization). More precisely, the main goal of this research is to examine the role of BIS, BAS, Fight, Flight and Freeze in predicting the adaptive and maladaptive aspects of perfectionism. By relying on rRST and the results of previous studies, the following hypotheses were set: 1) BIS is the strongest positive correlate for maladaptive evaluative concerns, while BAS has a negative association with this factor; 2) BIS and BAS represent positive correlates of positive striving; 3) Flight and Freeze are positive correlates of maladaptive evaluative concerns, and 4) Fight is a positive correlate of maladaptive and adaptive aspects of perfectionism.

\section{METHODOLOGY}

\subsection{The sample of participants and procedure}

The sample of this research included students of undergraduate studies from different departments at the Faculty of Philosophy in Niš (psychology, pedagogy, social policy and social work). Out of a total of 299 survey respondents, $79.3 \%$ (237) were female. The age ranged from 19 to 29 years $(\mathrm{M}=20.34 ; \mathrm{SD}=1.83)$. The respondents filled out the questionnaires using the paper-pencil method, and the survey was done in a group. It was anonymous and voluntary. The instructions to the survey respondents were given verbally 
and in writing. All of them were informed about the purpose of the research and their consent to participate in the research was obtained.

\subsection{Instruments}

The Reinforcement Sensitivity Questionnaire (RSQ; Smederevac et al., 2014) was used to assess personality systems postulated by the revised Reinforcement Sensitivity Theory. The questionnaire contained 29 items that included five measurement subjects, i.e., scales: 1) Behavioural Inhibition System (BIS) (7 items; e.g., "I often worry about being criticized"); 2) Behavioural Approach System (BAS) (6 items; e.g., "When I want something, I never think about possible obstacles"); 3) Fight (6 items; e.g., "When someone attacks me, I fight back without hesitation"); 4) Flight (5 items; e.g., "When I find myself in a dangerous situation, I look for all possible ways to escape"), and 5) Freeze (5 items; e.g., "I simply 'freeze' when I'm very scared"). The response format was a 4-level Likert scale (1 - completely disagree; 2 - somewhat disagree; 3 - somewhat agree; 4 - completely agree). With the exception of Flight, other scales incorporated within the RSQ showed satisfactory measurement reliability (BIS: $\alpha=.75$; BAS: $\alpha=.72$; Fight: $\alpha=.77$; Flight $=.52$; Freeze: $\alpha=71$ ). The unsatisfactory reliability of the Flight scale measurement can be partly explained by the small number of items. The lowest reliability of Flight measurements in relation to other RSQ scales was obtained in the research conducted by Smederevac et al. (Smederevac et al., 2014).

The Multidimensional Perfectionism Scale (MPS; Frost et al., 1990). The scale was translated and adapted to our linguistic environment by Stojiljković and Maksić in 1997. The MPS contains a total of 35 items with a five-level Likert scale as a response format (1 completely disagree; 2 - somewhat disagree; 3 - indecisive; 4 - somewhat agree; 5 completely agree). The scale includes 6 subscales, which are: 1) Concern over mistakes COM (9 items; e.g., "I should feel bad whenever I make a mistake"); 2) Personal standards PS (7 items; e.g., "It is important to me to be fully skillful in everything I do"); 3) Parental expectations PE (5 items; e.g., "My parents set very high expectations for me"); 4) Parental criticism PC (4 items; e.g., "I feel I have never met my parents' expectations"); 5) Doubts about actions DA (4 items; e.g., "Even when I do something very carefully, I often feel that it is not good enough"), and 6) Organization O (6 items; "I am someone who is wellorganized"). The MPS provides information on the total score (all subscales are taken into account, except for Organization), as well as on individual scores within the subscales. Moreover, the scale provides data on two factors of perfectionism, and those are: 1. Maladaptive evaluation concern - MEC (22 items), including the following subscales: Concerns about mistakes, Parental expectation, Parental criticism and Doubt about actions, and 2. Positive striving - PSt (13 items) which includes the subscales Personal standards and Organization. The reliability of the measurement scale as a whole is .90 , while the values of the internal consistency coefficient for individual scales in this study range from .73 to .88 (CM: $\alpha=.84$; PS: $\alpha=.77$; PE: $\alpha=.86$; PC: $\alpha=.86$; D: $\alpha=.73$; O: $\alpha=.88$ ). The measurement reliability of the MEC subscale is .92 , and the PSt subscale is .84 . Therefore, this is satisfactory measurement reliability, regardless of whether we are talking about the scale as a whole, or individual subscales. Such data have been obtained in previous studies in our region in a sample that included students (e.g., Milojević et al., 2009; Stojiljković et al., 2011; Todorović et al., 2009). 


\section{RESULTS}

\subsection{Descriptive indicators and intercorrelation of the main research variables}

Table 1 shows the main descriptive indicators of the variables used in this research such as minimum, maximum, means, standard deviations and Skewness and Kurtosis coefficients (Sk and $\mathrm{Ku}$ ). Regarding personality traits, the respondents showed a similar degree of acceptance of items which represent different personality systems. By reviewing the mean values of dimensions of perfectionism, we notice that the respondents showed a somewhat higher degree of agreement with items denoting Personal standards, Organization, and Positive strivings. Sk and $\mathrm{Ku}$ indicate that almost all the research variables (except for Parental criticism due to Skewness value) show normal distribution (Skewness and Kurtosis $+/-1$ ). None of the score normalization methods was applied for the purpose of further analysis, since we are talking about minor deviations. Therefore, one of the basic requirements for the usage of the proposed statistical technique for data analysis (hierarchical regression analysis) is met.

Table 1 Descriptive indicators of the values of research variables

\begin{tabular}{lrrrrrrr}
\hline & $\mathrm{N}$ & Min & Max & M & \multicolumn{1}{c}{ SD } & \multicolumn{1}{c}{ Sk } & $\mathrm{Ku}$ \\
\hline BIS & 299 & 1.00 & 4.00 & 2.39 & .60 & .028 & -.452 \\
BAS & 299 & 1.00 & 4.00 & 2.71 & .55 & -.045 & -.242 \\
Fight & 299 & 1.00 & 4.00 & 2.36 & .64 & .192 & -.376 \\
Flight & 299 & 1.00 & 3.80 & 2.64 & .56 & -.333 & -.012 \\
Freeze & 299 & 1.00 & 4.00 & 2.13 & .63 & .293 & -.195 \\
Concern over mistakes (CM) & 294 & 1.00 & 4.44 & 2.28 & .79 & .567 & -.232 \\
Personal standards (PS) & 299 & 1.43 & 5.00 & 3.29 & .75 & .058 & -.662 \\
Parental expectations (PE) & 297 & 1.00 & 5.00 & 2.13 & 1.03 & .955 & .046 \\
Parental criticism (PC) & 297 & 1.00 & 5.00 & 1.83 & 1.02 & 1.283 & .694 \\
Doubts about actions (DA) & 299 & 1.00 & 5.00 & 2.74 & .93 & .381 & -.441 \\
Organization (O) & 299 & 1.00 & 5.00 & 3.91 & .89 & -.962 & .628 \\
Maladaptive evaluation concern (MEC) & 299 & 1.00 & 4.38 & 2.25 & .75 & .814 & .171 \\
Positive striving (PSt) & 299 & 1.29 & 5.00 & 3.60 & .68 & -.508 & -.027 \\
\hline
\end{tabular}

Note. symmetry coefficient -Skewness (Sk); tailedness coefficient - Kurtosis (Ku).

The next step was to do a correlation analysis, to check if the second basic requirement for the usage of hierarchical regression analysis is met (significant correlation between a set of predictor variables (personality traits) and a set of criterion variables (dimensions of perfectionism), as well as the absence of multicollinearity (high correlation between predictors). However, bearing in mind that there is a noticeable disproportion between the number of male and female survey respondents, partial correlation was applied. In that way, statistical control of gender was possible. The results are shown in the following table.

Based on the abovementioned results of the correlation analysis, it can be concluded that there is no multicollinearity, i.e., no high correlation between predictor variables (personality traits). Moreover, there is a significant correlation between personality traits and perfectionism dimensions, ranging from .117 (BAS and Positive strivings) to .525 (BIS and Doubts about actions). Therefore, basic requirements for the application of the main statistical analysis in this research are met. When it comes to the intercorrelation 
between certain dimensions of perfectionism, they range from -.036 (MEC and O) to .866 ( $\mathrm{p}<.001 ; \mathrm{O}$ and PSt). The correlation between MEC and PSt is .169 ( $\mathrm{p}<.01)$.

Table 2 Inter-correlations between the research variables (partial correlations)

\begin{tabular}{|c|c|c|c|c|c|}
\hline & BIS & BAS & Fight & Flight & Freeze \\
\hline BIS & & $-.235^{* * * *}$ & -.053 & $.407^{* * *}$ & $.562^{* * *}$ \\
\hline BAS & & & $.279^{* * *}$ & -.044 & $-.249^{* * *}$ \\
\hline Fight & & & & .011 & -.111 \\
\hline Flight & & & & & .377 \\
\hline Concern over mistakes (CM) & $.456^{* * *}$ & $-.233^{* * * *}$ & .107 & $.239^{* * *}$ & $.365^{\text {**** }}$ \\
\hline Personal standards (PS) & $.149^{*}$ & $.220^{* * * *}$ & $.281^{* * *}$ & $.190^{* *}$ & .046 \\
\hline Parental expectations (PE) & $.188^{* *}$ & -.059 & .102 & $.129^{*}$ & $.219^{* * *}$ \\
\hline Parental criticism (PC) & $.209^{* * *}$ & $-.157^{* *}$ & .071 & .055 & $.258^{* * *}$ \\
\hline Doubts about actions (DA) & $.525^{* * *}$ & $-.238^{* * *}$ & .023 & $.176^{* *}$ & $.394^{* * *}$ \\
\hline Organization $(\mathrm{O})$ & .068 & -.007 & -.005 & .107 & .054 \\
\hline Maladaptive evaluation concerns (MEC) & $.407^{* * *}$ & $-.212^{* * * *}$ & .091 & $.179^{* *}$ & $.370^{* * * *}$ \\
\hline Positive strivings (PSt) & $.126^{*}$ & $.117^{*}$ & $.151^{* *}$ & $.174^{* *}$ & .060 \\
\hline
\end{tabular}

\subsection{Predicting perfectionism dimensions based on personality traits}

A step further in the data analysis was the hierarchical regression analysis. There were two reasons for this. Firstly, although there was no high correlation between different personality traits, there is still some variance that they share (Table 2). Therefore, hierarchical regression analysis is a suitable statistical technique for examining the predictor role of certain variables (Flight and Freeze) after the statistical control of the contribution of other predictors (BIS). Secondly, the results of the correlation analysis in this study (Table 2), but also in some previous studies (e.g., Chang et al., 2007; Randles et al., 2010), indicate that personality traits within oRST and rRST have different correlation values and contribute to the prediction of certain perfectionism dimensions. Therefore, there is justification that relies on empirical findings (e.g. Flett et al. 2002; O'Connor and Forgan 2007; Stoeber \& Corr 2015,2017$)$ that predictors should be included in a different order. Based on that, BIS was included in the first step of the first hierarchical regression analysis in this research (the criterion was Maladaptive evaluation concerns). Fight, Flight and Freeze were added in the second step. BAS was included in the last step. A slightly different order of predictor insertion was used in the second analysis, where the criterion was Positive strivings (first step -BAS; second step - Fight, Flight and Freeze, and third step - BIS). It is important to note that, due to uneven sampling with respect to gender, the prediction of personality traits and personality dimensions based on gender was performed first, and then the residuals were recorded. In that way, statistical control of gender was performed, and once that portion of the total variance that is explained by gender was removed, the variables were used in the main analysis. Therefore, the findings were not confounded by the prevalence of female respondents in the sample. The results are shown in Table 3 and Table 4.

Insight into the findings obtained shows that all three prediction models are significant. Moreover, the results justify the order of inclusion of predictors because they indicate the following: 1) As the only predictor, BIS explains most of the variance of MEC (Maladaptive evaluation concerns) (16.5\%); 2) The addition of Fight, Flight and Freeze reduces the independent contribution of BIS to MEC prediction, and the added predictors explain the additional $4.7 \%$ variance of the criteria, and 3) By including BAS, the percentage of explained 
MEC variance increases by another $1.8 \%$. Thus, when all personality systems are included as predictors of MEC, the percentage of explained variance is $23 \%$. When it comes to the direction and strength of the independent contribution of personality systems in the prediction of MEC, the data show that BIS is a consistent and the strongest positive correlate of the maladaptive aspect of perfectionism. It is followed by Freeze and Fight, and BAS makes a negative and the smallest contribution in predicting MEC. Flight does not have a significant role in predicting this criterion.

Table 3 Prediction of Maladaptive evaluation concerns based on personality dimensions

\begin{tabular}{cccc}
\hline Model & Predictors & Model summary & $\begin{array}{c}\text { Independent contributions of predictors } \\
\end{array}$ \\
\hline 1 & BIS & $\mathrm{R}=.407 ; \mathrm{R}^{2}=.165 ;$ \\
& & $\mathrm{F}(1,298)=58.639 ; \mathrm{p}<.001$ & $.407^{* * *}$ \\
\hline \multirow{2}{*}{2} & BIS & $\mathrm{R}=.461 ; \mathrm{R}^{2}=.212 ;$ \\
& Fight & $\mathrm{F}(4,298)=19.787 ; \mathrm{p}<.001$ & $.298^{* * *}$ \\
& Flight & $\mathrm{R}^{2}$ change $=.047$ & $.133^{*}$ \\
& Freeze & $\mathrm{F}$ change $(3,294)=5.820$ & -.030 \\
& & $\mathrm{p}<.001$ & $.228^{* * *}$ \\
\hline \multirow{4}{*}{3} & BIS & $\mathrm{R}=.480 ; \mathrm{R}^{2}=.230 ;$ & $.274^{* * * *}$ \\
& Fight & $\mathrm{F}(5,298)=17.512 ; \mathrm{p}<.001$ & $.169^{* * *}$ \\
& Flight & $\mathrm{R}^{2}$ change $=.018 ;$ & -.019 \\
& Freeze & $\mathrm{Fchange}(1,298)=6.841$ & $.205^{* *}$ \\
& BAS & $\mathrm{p}<.01$ & $-.145^{* * *}$ \\
\hline
\end{tabular}

Table 4 Prediction of Positive strivings based on personality dimensions

\begin{tabular}{|c|c|c|c|}
\hline Model & Predictors & Model summary & $\begin{array}{c}\text { Independent contributions of predictors } \\
B\end{array}$ \\
\hline 1 & BAS & $\begin{array}{c}\mathrm{R}=.117 ; \mathrm{R}^{2}=.014 \\
\mathrm{~F}(1,298)=4.091 ; \mathrm{p}<.05\end{array}$ & $.117^{*}$ \\
\hline 2 & $\begin{array}{c}\text { BAS } \\
\text { Fight } \\
\text { Flight } \\
\text { Freeze }\end{array}$ & $\begin{array}{c}\mathrm{R}=.247 ; \mathrm{R}^{2}=.061 ; \\
\mathrm{F}(4,298)=4.780 ; \mathrm{p}<.01 \\
\mathrm{R}^{2} \text { change }=.047 \\
\text { Fchange }(3,294)=4.955 \\
\mathrm{p}<.01\end{array}$ & $\begin{array}{l}.098 \\
.126^{*} \\
.163^{* *} \\
.037\end{array}$ \\
\hline 3 & $\begin{array}{l}\text { BAS } \\
\text { Fight } \\
\text { Flight } \\
\text { Freeze } \\
\text { BIS }\end{array}$ & $\begin{array}{c}\mathrm{R}=.262 ; \mathrm{R}^{2}=.069 ; \\
\mathrm{F}(5,298)=4.313 ; \mathrm{p}<.01 \\
\mathrm{R}^{2} \text { change }=.007 ; \\
\text { Fchange }(1,293)=2.357 \\
\mathrm{p}>.05\end{array}$ & $\begin{array}{l}.111 \\
.123^{*} \\
.137^{*} \\
-.012 \\
.109\end{array}$ \\
\hline
\end{tabular}

The results of the second hierarchical regression analysis also show the significance of all three prediction models. However, when BAS is the only predictor of Positive striving (PSt), then the percentage of explained variance of this criterion is only $1.4 \%$. By adding Fight, Flight and Freeze, the contribution of BAS to the prediction of this criterion decreases, and it also becomes an insignificant predictor. When controlling the contribution of BAS to the PSt prediction, there is a significant change in the percentage of explained variance of the criterion for FFFS, increasing it to another 4.7\%. And lastly, by including BIS in the last step of the analysis, the percentage of explained variance increases by $0.7 \%$, but this 
increase is not statistically significant. When observing this model with all personality systems as predictors, the explained percentage of PSt variance is $6.9 \%$.

If the direction, size and significance of predictive contributions of the personality system are taken into account, then the following can be observed: 1) BAS is neither consistent nor the strongest positive correlate of PSt; 2) When controlling the contribution of BAS to PSt prediction, Fight and Flight are seen as positive correlates of PSt; 3) By adding BIS to the model, Fight and Flight still retain the significance of their predictive contribution, with the same direction, but slightly lower regression coefficients compared to Model 2, and 4) BIS is not a significant predictor of PSt.

\section{DISCUSSION AND CONCLUSIONS}

The main goal of this research was to examine perfectionism in the context of the Revised Reinforcement Sensitivity Theory. In other words, we were interested in which personality traits from rRST can explain two aspects of perfectionism - Maladaptive evaluation concerns and Positive strivings. Therefore, two separate hierarchical regression analyses were performed. These analyses had the same set of predictors, but a different order of inserting the predictors into the models, which was conditioned by different criteria. The results show that BIS is a robust and positive predictor of Maladaptive evaluation concerns. It is followed by Freeze and Fight. There was no significant predictive role of Flight observed. Unlike personality defence systems, BAS is a negative correlate of the criterion in question and has the smallest independent contribution in predicting it. This structure of results was generally expected.

These findings above all indicate that people with expressed maladaptive evaluation concerns are actually people with hypersensitive BIS. This means that these people are prone to experiencing tension, worry and anxiety. They often worry that they will be criticized and receive negative evaluation from others, and find it difficult to make decisions that require a choice between several options, as well as uncertainty. Since BIS is a system of defensive approach to risk assessment, this would mean that maladaptive perfectionists often overemphasize the threatening component of certain events and situations and that this evaluation may be irrational. Moreover, in people with prominent maladaptive evaluation concerns, the irrationality of the assessment may also be directed towards the assessment of their own results and actions. It is well-known that such people are overly critical of themselves, the standards of their actions and accomplishments, and that they are often dissatisfied with their own achievements (Shafran \& Mansell 2001; Slade \& Owens 1998). Furthermore, one of the functions of BIS is behaviour control by initiating reactions from other personality systems. In this regard, reactions within Freeze and Fight (as predictors that are second in order of importance) may represent favoured attempts by dysfunctional perfectionists to defend themselves from threatening reality. More specifically, these individuals set unrealistically high standards and goals for themselves (Shafran \& Mansell 2001; Slade \& Owens 1998), and their failure to achieve these causes frustration which can further trigger panic and aggressive reactions. Moreover, based on these results, it can be concluded that maladaptive perfectionism is associated with assessments of the impossibility to avoid threats (Freeze), and uncertainty about defence against threats (Fight). In other words, feeling that it is uncertain or impossible to avoid unachieved parental expectations and criticism, as well as concern about one's own mistakes and doubts about 
one's actions makes a person prone to panic and hostile reactions. This is consistent with the understanding of the maladaptive character of perfectionism by Rice and Slaney (Rice \& Slaney 2002). These authors claim that the dysfunctionality of perfectionism is reflected through the inability to achieve and sustain high goals (expressed, for example, through parental expectations). The findings obtained also indicate a positive association between negative affectivity (BIS:Anxiety, Freeze:Panic, and Fight:Anger) and MEC, which is consistent with numerous findings from previous studies (e.g., Frost et al., 1993; a detailed review of these studies can be found in Stoeber \& Otto 2006).

One of the initial premises of this research was that Flight will be an important predictor of maladaptive perfectionism, because the fear of failure and the tendency to avoid failure and its consequences are the basis of the dysfunctional component of perfectionism. Although it could seemingly be concluded that the findings of this study do not support the above premise, it should be noted that the findings should be taken with a grain of salt. Here is why. The results of the correlation analysis show that there is a significant positive but low correlation between Flight and MEC, but also with certain dimensions of perfectionism within MEC; however, Flight does not have significant role in predicting this criterion. In contrast, at the correlation level there is no significant correlation between Fight and certain dimensions of MEC, as well as MEC itself. However, the results of the regression analysis show that Fight is a significant predictor of MEC. This set of findings could indicate the complexity of the relationship between the personality system from rRST, but also the possible moderating effect of certain variables on the relationship between personality traits and maladaptive perfectionism. Therefore, specifying the conditions under which there is an association between two variables is a very important and complex task. In other words, such result structure can be a guideline for researchers to specify and study possible moderators in the relationship between these constructs in their future studies on the relationship between Gray's model of personality and perfectionism. Properly defined and tested moderators of the relationship between personality traits and perfectionism can represent the very essence of the connection between these phenomena.

The negative association between BAS and maladaptive evaluation concerns indicates that elevated BAS activity is a protective factor in neurotic or dysfunctional perfectionism. In other words, a more pronounced tendency towards positive emotions, approach behaviour that is impulsive, as well as increased sensitivity to reward signals and punishment avoidance will reduce the negative effects of maladaptive perfectionism. This is an important finding, because in combination with the previously presented results, it indicates that people with increased BIS and FFFS activation and reduced BAS reactivity are more prone to the maladaptive form of perfectionism. Therefore, in the context of rRST, maladaptive perfectionist aspirations can be explained as simultaneously increased sensitivity to negative reinforcement with decreased sensitivity to positive reinforcement. More precisely, from the perspective of Gray's model of personality, maladaptive perfectionism can be described as an increased tendency towards negative feelings, resulting from impossibility or insecurity that it might be possible to avoid failure, along with a reduced tendency to experience positive emotions which is an accompanying component of reduced sensitivity and reactivity to positive reinforcement (such people do not enjoy their accomplishments). This is consistent with what other authors call neurotic, negative, or dysfunctional perfectionism (e.g., Frost et al. 1993; Slade \& Owens 1998; Stoeber \& Otto 2006). Moreover, the findings obtained are partly in line with past empirical evidence (Flett et al. 2002; Kaye et al. 2008; O'Connor \& Forgan 2007; Randles et al. 2010; Stoeber \& Corr 2015, 2017). Given that previous studies 
focused on the relationship between the oRST/rRST personality system and Hewitt and Flett's model of perfectionism, future research efforts need to be directed toward verifying the relationship between rRST and the model of perfectionism developed by Frost et al. This would contribute to supplementing and verifying empirical data on this research problem.

Considering Positive Strivings as a criterion, the findings are somewhat different. Although all three predictive models are significant, there are differences compared to the previously explained results. These differences are related to: 1) different significant predictors of PSt in relation to significant predictors of MEC (in the first model - BAS with only $1.4 \%$ of the explained variance of the criteria, and in the second and third model Flight and Fight with $4.7 \%$ of the additional explained variance of PSt); 2) lower percentage of explained variance of criteria in models that include all personality systems (MEC as a criterion: 23\%; PSt as a criterion: 6.9\%), and 3) BIS is not a significant predictor of PSt.

Given that PSt refers to the positive or adaptive aspect of perfectionism, the assumption was that BAS would be its strongest and most consistent positive predictor, but the findings do not confirm this. Instead, the results show that Flight and Fight explain PSt the most, and the direction of their correlation is positive. The fact that BAS stands out as a significant predictor only in the first step of the analysis, with a very small percentage of explained variance, can be explained by defining and operationalizing BAS and personal standards as a dimension that is part of Positive strivings. Namely, BAS is activated when there are sufficiently challenging stimuli that a person perceives as a potential reward. It is personal standards that have these characteristics (for example, I have extremely high goals). However, the Personal Standards subscale is not defined by impulsive approach behaviour, which is an essential part of BAS. On the other hand, Personal Standards are operationalized through behaviours that relate to the perseverance and persistence in achieving goals (e.g., I can direct my energy to achieve a goal). Moreover, BAS is operationalized through behaviours related to the tendency not to miss any pleasure in life. On the other hand, Personal Standards refer to setting high demands and standards, which can be at odds with the hedonistic lifestyle. Overall, the assumption is that a small part of the explained variance of PSt can be attributed to the part of the BAS that is responsible for accepting new and exciting situations. Although BAS is not a robust correlate of PSt, the direction of their correlation is consistent with data from previous studies (Flett et al. 2002; Kaye et al. 2008; O’Connor \& Forgan 2007; Randles et al. 2010; Stoeber \& Corr 2015, 2017).

When looking at the data from the correlation analysis, it can be seen that BAS is positively correlated with Personal Standards, but not with Organization. Also, it is interesting that no personality system from rRST correlates with this dimension of perfectionism. The reason for this may be that Organization is defined and operationalized in a similar way as the facet of Conscientiousness dimension from the FFM - Five-Factor Model (Order orderliness, good organization) and which refers to the character of the person. Since Gray's model of personality covers only the dimensions of temperament, these findings were to be expected. Therefore, for a complete explanation of perfectionism, it is necessary to include some of the psychobiological models that postulate the dimensions of temperament and character. Therefore, the recommendation for further studies is to choose Cloninger's psychobiological model of personality as a suitable reference framework for studying perfectionism.

Data on Flight and Fight as consistent and positive correlates of PSt suggest a somewhat different view of the nature of this aspect of perfectionism. Activation of Flight is 
accompanied by fear and avoidance of danger, while activation of Fight is associated with anger and defensive aggression due to the assessment of insecurity to avoid threats. This means that setting high goals and standards of achievement is motivated by fear and danger avoidance (fear of failure and avoiding its consequences), which is an indicator of the negative side of perfectionism. This can interfere with the accomplishments of perfectionists and can lead to procrastination due to the fear of failure. Constant postponement of obligations due to the fear of failure is what makes perfectionism a potentially maladaptive personality trait (Milojević et al., 2009; Stojiljković et al., 2011). Furthermore, people who are prone to setting the highest requirements and criteria of perfection are more likely to experience anger and express defensive aggression. The assumption is that such people are more inclined to set unrealistically high demands that are not easy to fulfil, and they react with anger and aggression in order to defend themselves from failure. Due to the characteristics of adaptive, that is, positive perfectionism, different results were expected (negative association between these personality systems and PSt). Adaptive perfectionism is associated with a high level of aspiration and pursuit of perfection, but not in order to defend one's self-image, but in order to realize one's own potential. However, the findings of this study indicate that in the context of rRST, Positive strivings can be explained as a neurotic personality trait. It should be emphasized that there is a significant low but positive correlation between MEC and PSt, which may suggest that these two aspects of perfectionism share somewhat common characteristics. This is understandable because these are two aspects of the perfectionism phenomenon. In this case, this can refer to the negative implications of this personality trait.

Practical implications of the results of this research can be reflected in the design and organization of workshops, seminars and courses for parents and students. The main goal of such education would be to learn to recognize the positive and negative aspects of perfectionism, as well as to adopt techniques that would reinforce the functional aspects of this personality trait, and reduce the dysfunctional ones. Parents should be made aware of the importance of setting high goals and standards of achievement for their children, in order to encourage the development of their potential. However, parents should master the skills which will help them not to set unrealistically high goals for their children, not to show excessive criticism, as well as dissatisfaction and fear of failure. This is especially important for children who by nature have a greater tendency to experience negative emotions, and a reduced tendency to experience positive emotions. As a reminder, the findings of this research indicate that people with such temperament traits are a risk group for the development of negative aspects of perfectionism. Finally, students can gain insight into the origins of unrealistic expectations and imperatives of perfection (parental expectations and/or high competitiveness in the wider social context). They can also learn to set goals that are in line with their abilities and desires, as well as to enjoy their own accomplishments.

\section{REFERENCES}

Blankstein, Kirk R., Lumley Crystal Hillis, and Alison Crawford. "Perfectionism, hopelessness, and suicide ideation: Revisions to diathesis-stress and specific vulnerability models". Journal of Rational-emotive and Cognitive Behavior Therapy, 25 (2007): 279-319.

Changa, Edward, C., Kathryn M. Zumberga, Lawrence J. Sannab, Laura P. Girza, Allison M. Kadea, Sarah R. Shaira, Nicole B. Hermanna, and Kavita Srivastava. "Relationship between perfectionism and domains of worry in a college student population: Considering the role of BIS/BAS motives". Personality and Individual Differences 43 (2007): 925-936. 
Corr, Philip, J., and Andrew Cooper A. "The reinforcement sensitivity theory personality scales (RST-PQ): Development and validation". Psychological Assessment 28, 11 (2016): 1427-1440.

Depue, Richard, A., and Paul F. Collins. "Neurobiology of the structure of personality: Dopamine, facilitation of incentive motivation, and extraversion". Behavioral and Brain Sciences 22, 3 (1999): 491-517.

Flett, Gordon, L., Avi Besser, Richard A. Davis, and Paul L. Hewitt. "Dimensions of perfectionism, unconditional selfacceptance, and depression". Journal of Rational-emotive and Cognitive Behavior Therapy 21 (2003): 119-138.

Flett, Gordon, L., Kirk R. Blankstein, Paul L. Hewitt, and Spomenka Koledin."Components of perfectionism and procrastination in college students". Social Behavior and Personality 20 (1992): 85-94.

Flett, Gordon, L., Paul L. Hewitt, Kir, R. Blankstein, and Shawn W. Mosher. "Perfectionism, self-actualisation, and personal adjustment". Journal of Social Behavior and Personality 6 (1991): 147-150.

Flett, Gordon, L., Paul Hewitt, L., Joan Oliver M., and Silvana Macdonald. "Perfectionism in children and their parents: A developmental analysis". In Perfectionism: Theory, Research, and Treatment edited by Gordon, L. Flett, Paul L. Hewitt, 89-132. Washington, DC: American Psychological Association, 2002.

Frost, Randy, O., Richard Heimberg G., Craig Holt S., Jill Mattia I., and Amy Neubauer L."A comparison of two measures of perfectionism". Personality and Individual Differences 14 (1993): 119-126.

Frost, Randy, O., Patricia Marten, Cathleen Lahart, and Robin Rosenblate. "The dimensions of perfectionism". Cognitive Therapy and Research 14 (1990): 449-468.

Gray, Jeffrey A. The Psychology of Fear and Stress (2nd ed.). Cambridge, England: Cambridge University Press, 1987.

Gray, Jeffrey A., and Neil McNaughton. The Neuropsychology of Anxiety: An enquiry into the Functions of the Septo-hippocampal System (2nd ed.). New York: Oxford University Press, 2000.

Hewitt, Paul, L., and Gordon Flett L. Multidimensional Perfectionism Scale (MPS): Technical Manual. Toronto, Canada: Multi-Health Systems, 2004.

Frost, Randy, O., Richard Heimberg G., Craig Holt S., Jill Mattia I., and Amy Neubauer, L. "A comparison of two measures of perfectionism". Personality and Individual Differences 14 (1993):119-126.

Hamachek, Don, E. "Psychodynamics of normal and neurotic perfectionism". Psychology 15 (1978): 27-33.

Hewitt, Paul, L., and Gordon Flett L. "Perfectionism in the self and social contexts: Conceptualization, assessment, and association with psychopathology". Journal of Personality and Social Psychology 60, 3 (1991): 456-470.

Kaye, Miranda, P., David Conroy E., and Angela Fifer M. "Individual differences in incompetence avoidance". Journal of Sport and Exercise Psychology 30 (2008): 110-132.

Klibert, Jeffrey J., Jennifer Langhinrichsen-Rohling, and Motoko Saito. "Adaptive and maladaptive aspects of self-oriented versus socially prescribed perfectionism". Journal of College Student Development 46 (2005): $141-156$.

Krupić Dino, and Bojana Dinić. "Situational cues trigger Risk assessment, Fight, Flight, but not Freeze in Blanchard's threat scenarios". Human Ethology Bulletin 32, 2 (2017): 14-23.

Lo, Alice, and Maree Abbott J. "Review of the theoretical, empirical, and clinical status of adaptive and maladaptive perfectionism". Behaviour Change 30 (2013): 96-116.

Milojević, Milica, Snežana Stojiljković, Jelisaveta Todorović, i Kristina Kašić. "Ciljevi postignuća i perfekcionizam gimnazijalaca". Psihologija 42, 4 (2009): 517-534.

O’Connor, Rory, C., and Grant Forgan. "Suicidal thinking and perfectionism: The role of goal adjustment and behavioral inhibition/activation systems (BIS/BAS)". Journal of Rational-Emotive and Cognitive Behavior 25 (2007): 321-341.

Randles, Daniel, Gordon Flett L., Kyle Nash, A., Ian McGregor D., and Paul Hewitt L. "Dimensions of perfectionism, behavioral inhibition, and rumination". Personality and Individual Differences 49 (2010): 83-87.

Ranđelović, Kristina. "Efekti socijalne pretnje i tipa povratne informacije na kognitivne pristrasnosti $i$ socijalnu anksioznost" [The effects of social threat and type of feedback on cognitive biases and social anxiety] (Doctoral dissertation). Faculty of Philosophy, University of Novi Sad, Serbia, 2016. Retrieved from http://nardus.mpn.gov.rs/handle/123456789/6583

Ranđelović, Kristina, Snežana Smederevac, Petar Čolović, and Philip Corr. "Fear and anxiety in social setting: An experimental study". Journal of Individual Differences 39, 2 (2018): 61-75.

Saboonchi, Frederik, and Lars-Gunnar Lundh. "Perfectionism, anger, somatic health, and positive affect". Personality and Individual Differences 35 (2003): 1585-1599.

Shafran, Roz, and Warren Mansell. "Perfectionism and psychopathology: A review of research and treatment". Clinical Psychology Review 21 (2001): 879-906.

Slade, Peter, D., and Glynn Owens, R. "A dual process model of perfectionism based on reinforcement theory". Behavior Modification 22 (1998): 372-390.

Slaney, Robert, B., Kenneth Rice G., Michael Mobley, and Joseph Trippi. "The Revised Almost Perfect Scale". Measurement and Evaluation in Counseling and Development 34 (2001): 130-145. 
Smillie, Luke, D., Alan Pickering D., and Chris Jackson J. "The new reinforcement sensitivity theory: Implications for personality measurement". Personality and Social Psychology Review 10 (2006): 320-335.

Smederevac, Snežana, Dušanka Mitrović, Petar Čolović, and Željka Nikolašević. "Validation of the measure revised reinforcement sensitivity theory constructs". Journal of Individual Differences 35, 1 (2014): 12-21.

Stoeber, Joachim. "Multidimensional perfectionism and the DSM-5 personality traits". Personality and Individual Differences 64 (2014): 115-120.

Stoeber, Joachim. "How other-oriented perfectionism differs from self-oriented and socially prescribed perfectionism: Further findings". Journal of Psychopathology and Behavioral Assessment 37 (2015): 611-623.

Stoeber, Joachim, and Philip Corr, J. "Perfectionism, personality, and affective experiences: New insights from revised Reinforcement Sensitivity Theory". Personality and Individual Differences 86 (2015): 354-359.

Stoeber, Joachim, and Philip Corr J. "Perfectionism, personality, and future-directed thinking: Further insights from revised Reinforcement Sensitivity Theory". Personality and Individual Differences 105 (2017): 78-83.

Stoeber, Joachim, Philip Corr J., Martin Smith, M., and Don Saklofske H. "Perfectionism and personality". In The Psychology of Perfectionism: Theory, Research, Applications, edited by Joachim Stoeber, 68-88. London: Routledge, 2018.

Stoeber, Joachim, and Kathleen Otto. "Positive conceptions of perfectionism: Approaches, evidence, challenges". Personality and Social Psychology Review 10, 4 (2006): 295-319.

Stojiljković, Snežana. "Perfekcionizam: zdrava ili nezdrava težnja ka visokom postignuću". Psihologija danas 3 (1998): 36-37.

Stojiljković, Snežana, Jelisaveta Todorović, Zvonimir Dosković, i Dušan Todorović. "Razlike u perfekcionizmu srpskih i makedonskih studenata". Zbornik instituta za pedagoška istraživanja 43, 2 (2011): 312-329.

Todorović, Dušan, Ljubiša Zlatanović, Snežana Stojiljković, i Jelisaveta Todorović. "Povezanost perfekcionizma sa samopoštovanjem i depresivnošću kod studenata". Godišnjak za psihologiju 6, 8 (2009): 173-184.

\section{PERFEKCIONIZAM U KONTEKSTU REVIDIRANE TEORIJE OSETLJIVOSTI NA POTKREPLJENJE}

Osnovni cilj ovog istraživanja bio je ispitivanje uloge osobina ličnosti u predikciji dva aspekta perfekcionizma - maladaptivne evaluativne brige i pozitivna stremljenja. Osobine su postulirane revidiranom Teorijom osetljivosti na potkrepljenje, dok su dimenzije perfekcionizma definisane modelom perfekcionizma Frosta i saradnika. Uzorak je činilo 299 studenata Filozofskog fakulteta u Nišu (79.3\% je ženskog pola), starosti od 19 do 29 godina $(M=20.34 ; S D=1.83)$. Od instrumenata korišćeni su: Upitnik osetljivosti na potkrepljenje (UOP) i Multidimenzionalna skala perfekcionizma (MPS). Glavni podaci istraživanja su da je Sistem bihejvioralne inhibicije (BIS) najjači i pozitivni korelat maladaptivnih evaluativnih briga, a slede ga Blokiranje i Borba. Sistem bihejvioralne aktivacije (BAS), za razliku od odbrambenih sistema ličnosti, ostvaruje negativnu vezu sa pomenutim kriterijumom. Ukupni procenat objašnjene varijanse maladaptivnih evaluativnih briga iznosi 23\%. Kada je kriterijum pozitivna stremljenja, BAS samo u prvom koraku hijerarhijske regresione analize predstavlja pozitivni korelat. Međutim, Bežanje i Borba predstavljaju dosledne $i$ pozitivne korelate ovog kriterijuma. Ukupan procenat objašnjene varijanse pozitivnih stremljenja je 6.9\%. Nalazi su u skladu sa revidiranom Teorijom osetljivosti na potkrepljenje i dostupnim empirijskim nalazima prethodnih istraživanja. Takođe, rezultati ukazuju da se u kontekstu pomenute teorije ličnosti, maladaptivne evaluativne brige i pozitivna stremljenja mogu shvatiti kao maladaptivne forme perfekcionizma, što odstupa od dosadašnjih shvatanja perfekcionizma.

Ključne reči: perfekcionizam, maladaptivne evaluativne brige i pozitivna stremljenja, revidirana Teorija osetljivosti na potkrepljenje. 